\title{
The Impact of Marketing Communication in Attracting Customer (Case Study at Fairmont Hotel Jakarta)
}

\author{
Yuan Reza Maulana Natakusumah ${ }^{1 *}$, Adinoto Nursiana ${ }^{2}$, Chondro \\ Suryono $^{3}$ \\ 1,3Sekolah Tinggi Pariwisata Trisakti \\ 2 Sekolah Tinggi Ilmu Ekonomi Wiyatamandala \\ *email_oke@yahoo.com
}

\begin{abstract}
Fairmont Hotel Jakarta has the unstable occupancy from month to month, started from January to December 2016. The objective of this research is to know the impact of marketing communication in attracting customer at Fairmont Hotel Jakarta. This research used associative casual. Population are all the guests who stayed in Fairmont Hotel Jakarta in the year of 2016. The sampling technique is non-probability sampling, and used incidental sample. The number of sample in this research is 120 respondents. Data was collected by distributing questionnaires with Likert scale. The statements in the questionnaires were tested of their validity and reliability. The data was analysed by using SPSS 19.0. The study found that marketing communication that consisted of advertising, sales promotion, public relation, personal selling and direct marketing impacted to attract customers $22,9 \%$.
\end{abstract}

Keywords: Advertising, Sales Promotion, Public Relation, Personal Selling, Direct Marketing 


\section{A. Introduction}

Marketing is the art of attracting and keeping profitable customers (Kotler and Keller, 2006). By using marketing strategy, Fairmont Hotel Jakarta will have an opportunity to attract customers and to keep them by using the tools of advertising, sales promotion, public relation, personal selling and direct marketing. Each promotional tool has its own unique characteristics and costs (Kotler, 2000).

There are many considerations in choosing a hotel to stay for travelers. In fact, some customers even value location above other aspects they see in a hotel and these people are willing to pay extra cost in order to satisfy their need in terms of location. With its strategic location, Fairmont Hotel Jakarta location is easier to find and this can be considered as a strong point for a new hotel in in Jakarta. Nevertheless, according to the Head Marketing Manager of Fairmont Hotel Jakarta, although the location is very strategic however it does not mean that Fairmont Hotel Jakarta is not facing obstacles in attracting customers. It can be seen from the occupancy. In the first year, Fairmont Hotel Jakarta appear in the market, which is $34,35 \%$.

With above obstacles the hotel faces, Fairmont Hotel Jakarta needs an effective marketing communication to convey the message to the market target. In any hospitality industry, marketing communication holds an important role in order to build a new brand, to attract new customers or even to maintain loyal customers. Hence, based on above explanation, it is interesting to conduct a research regarding the impact of marketing communication of Fairmont Hotel Jakarta in attracting the customer.

The study focused on the impact of marketing communication of Fairmont Hotel Jakarta to attract customers. The study objectives are to analyze:

1. the impact advertising to attracting costumer Fairmont Hotel Jakarta.

2. the impact sales promotion to attracting costumer Fairmont Hotel Jakarta.

3. the impact public relations to attracting costumer Fairmont Hotel Jakarta.

4. the impact personal selling to attracting costumer Fairmont Hotel Jakarta.

5. the impact direct marketing to attracting costumer Fairmont Hotel Jakarta.

\section{B. Literature Review}

"Companies use marketing communications to persuade target customers that their service product offers the best solution to meet those customers' needs, relative to the offerings of competing firms. Communication efforts serve not only to attract new users but also to maintain contact with an organization's existing customers and build relationships with them. Marketing communications is used to convince potential and current customers about the firm's superior performance on determinant attributes" (Wirtz, Chew \& Lovelock, 2013: 190). 
Companies must allocate the promotion budget over the five promotional tools, advertising, sales promotion, public relations and publicity, personal selling and direct marketing. Each promotional tool has its own unique characteristics and costs (Kotler, 2000). Therefore, marketing communication is an essential strategy to attract the customers as it is important for any kind of business, including hospitality. There are several of customer's characteristics; marketing communication is expected to help the company to deliver their message through the promotional tools above to any kind of customers.

In order to attract customers, marketing communication is an important tool to achieve this goal. Marketing communication can be a good stimulation for the customers to get to know the product and service, and to decide whether the product or service is attractive for them. This marketing communication is one of the strategies of Fairmont Hotel Jakarta to attract customers, explained as below framework:

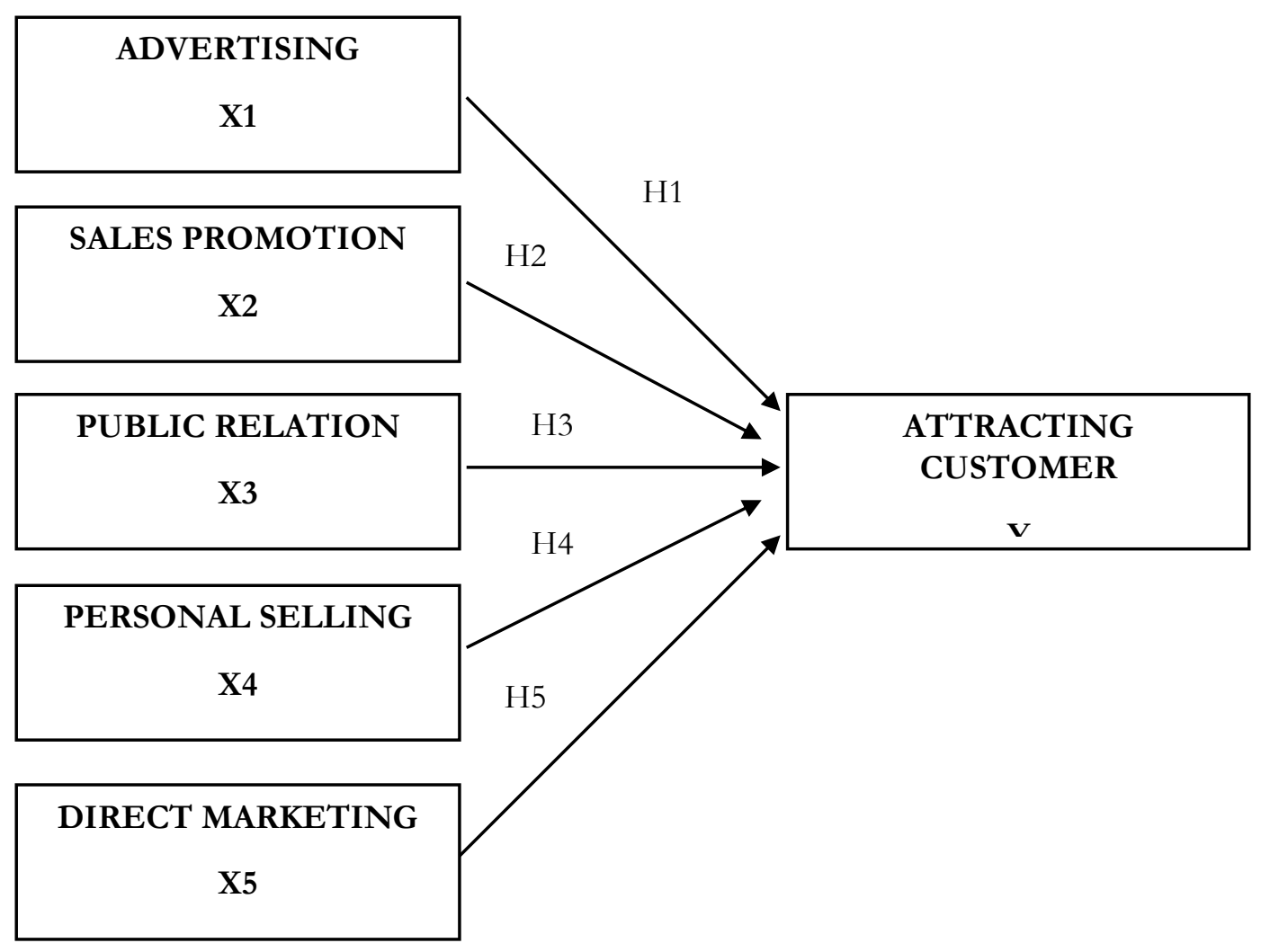

Based on above conceptual framework, it is decided that the independent variables of this research are advertising (X1), sales promotion (X2), personal selling (X3), public relation (X4), and direct marketing (X5); and the dependent variable is attracting customer $(\mathrm{Y})$.

The definition of each variable are as follow: 
1. Advertising (X1) is a promotion tool that is used by a company to persuade customer to buy the product or service the company offer. Advertisement believed to cover all target audience. Advertisement shows its attractiveness of the product or service they offer. Indicators are advertisement frequency, advertising awareness, and advertising attractiveness.

2. Sales Promotion (X2) is a promotion tool of various offers with purpose of getting customer's attention to decide quickly in purchase the product or service. Customers can decide quickly because the offer is so attractive and usually only valid for certain period of time. Indicators are promotion program, special events and content of the programs.

3. Public Relation (X3) is to build brand awareness and maintain good brand image of the company. Indicators are CSR program, sponsorship program, the way of PR handling issues and message content of the public relation program.

4. Personal Selling (X4) is a promotion tool involving sales person to direct selling the product or service to attract customer's attention. Indicators are the personality of sales person, competency of sales person \& customer satisfaction in receiving the offer of the sales person.

5. Direct Marketing (X5) is to offer specific promotional offer to specific target audience. Direct marketing can be done through email, mobile messaging or telemarketing. Indicators are direct marketing respond, regular promotional update, and attractiveness of the message.

6. Attracting Customer (Y) or customer's attraction is the time when the customers find the attractive product or service. Indicators are reason to do transaction and attractiveness of marketing communication from the company.

Marketing communication is an important role in every company to introduce and offer its products and services to customer. Attracting customers and potential customers' attention is essential to the growth of company. Therefore, marketing communication is important part of Fairmont Hotel Jakarta to attract its customers.

1. Impact of Advertising to attract customer

Based on previous research, it is explained that advertising main purpose is to persuade the customers to buy more the products and services (Holm, 2006).

H1: Advertising has a positive impact to attract customer.

2. Impact of Sales Promotion to attract customer

Based on previous research, it is explained that sales promotion is the most effective way of promotion in the business and customers find it very attractive to buy products (Morgan and Hunt, 2004). Furthermore, psychological investigations show that rewards can be highly motivating (Verhoef, 2003). 
The Impact of Marketing Communication in Attracting Customer (Case Study at Fairmont Hotel Jakarta)

H2: Sales promotion has a positive impact to attract customer.

3. Impact of Public Relation to attracting customer

Based on previous research, it is explained that without public relation the brands image is not build and the most of customer are unaware of the brands (Wesson, 2003).

H3: Public relation has a positive impact to attract customer.

4. Impact of Personal Selling to attract customer

Based on previous research, it is explained that direct selling is a good approach to ensure customers satisfaction and most of renowned companies in UK are using direct selling strategy to personally handling customers in order to build good relationship with them (Tusar, 2014).

H4: Personal selling has a positive impact to attract customer.

5. Impact of Direct Marketing to attract customer

Based on previous research, by direct marketing customers get more satisfaction and convenience from the company (Velde, 2007).

H5: Direct marketing has a positive impact to attract customer.

Most of the customers of Faimont Hotel Jakarta are considered as Generation $\mathrm{X}$, which is age 31-50 yo who are more dominant than younger age. According to Journal of Behavioral Studies in Business, the characteristics, lifestyles, and attitudes of Generation X include balancing family, life, and work (Williams and Page: 2017). Hence, this means that the people who come to Fairmont Hotel Jakarta are those with stable career and income compare to other generations, such as generation $\mathrm{Y}$.

With this in mind, can be concluded that getting attention from generation $\mathrm{x}$ is not easy and when successful in doing it, this type of respondent can be considered as highest-value customers. Not only their capability for higher consumption, but also the possibility of getting their loyalty once trust is earned.

\section{Research Methodology}

This research used descriptive quantitative method. The independent variables were advertising, sales promotion, public relation, personal selling and direct marketing and dependent variables was attracting customer. The Primary data was collected by distributing questionnaires. The questionnaire used Likert scale of 1 to 5 (Strongly disagree to strongly agree). Secondary data was collected from textbooks, websites, journals, and the company profile and information of Fairmont Hotel Jakarta. The data was analyzed by the test of validity, reliability, frequencies, normality test, multicollinearity, multiple regression (t-test), f-test, hypothesis, and coefficient determination. The data was analyzed by using SPSS version 21 .

TRJ Tourism Research Journal, Volume 1 (1), 2017 
Hypothesis test is called multiple regression test (t-test). According to Riduwan (2010), the formula is: $Y=a+b^{1} x^{1}+b^{2} x^{2}+b_{3} x_{3}+b_{4} x_{4}+b_{5} x_{5}$ $\mathrm{Y}=$ Attracting customer; $\mathrm{X}_{1}=$ Advertising; $\mathrm{X}_{2}=$ Sales promotion; $\mathrm{X}_{3}=$ Public relation; $\mathrm{X}_{4}=$ Personal selling; $\mathrm{X}_{5}=$ Direct marketing; $\mathrm{a}=$ Constants; $\mathrm{b}=$ Regression coefficient.

Simultan Test (f-test) is conducted to test whether simultaneously independent variable is able to explain dependent variable efficiently. If $\mathrm{f}$ value is smaller than 0,05, it meant that the regression equation is dependable.

Coefficient determination $\left(\mathrm{R}^{2}\right)$ is basically measuring how far the model in explaining the variation of related variable. Score of coefficient determination is between zero and one. Score small $\mathrm{R}^{2}$ means the capability of related variables are very limited. Score closer to one are the independent variables are giving almost all information needed to predict variation of independent variable.

\section{Result and Discussion}

\section{Frequencies}

Respondents' characteristics could be seen in table 1. According the data on table 1 , the percentage of male is $59,16 \%$ and female is $40,87 \%$.

In the point of age, most of the customers of Faimont Hotel Jakarta are considered as Generation X, which is age $31-50$ yo who are more dominant than younger age. According to Journal of Behavioral Studies in Business, the characteristics, lifestyles, and attitudes of Generation X include balancing family, life, and work (Williams and Page: 2017). Hence, this means that the people who come to Fairmont Hotel Jakarta are those with stable career and income compare to other generations, such as generation Y. It can be concluded that getting attention from generation $\mathrm{x}$ is not easy and when successful in doing it, this type of respondent can be considered as highest-value customers. Not only their capability for higher consumption, but also the possibility of getting their loyalty is earned.

Research found that people in higher socio-economic levels are more likely to complain than those in lower levels. Their better education, higher income, and greater social involvement give them the confidence, knowledge and motivation to speak up when they encounter problems (Witz, Chew \& Lovelock: 2012). Hence, besides the possibility of getting highest-value customers with mature age it should be understood as well that the combination between that and high education can be both opportunity and threat to Fairmont Hotel Jakarta.

Based on the respondents occupation, it can be concluded that corporates are more dominant than other work field in terms of Fairmont Hotel Jakarta 
customers. One of the reasons because the Fairmont Hotel Jakarta is located in the heart of the city and surrounded by business districts.

The respondents visit Fairmont Hotel Jakarta once in a month. They usually have certain needs, leisure or work. These customers are loyal customers who come to Fairmont Hotel Jakarta consistently. Furthermore, those who visits Fairmont Hotel Jakarta for 2-7 times a month are usually those with routine meeting or work purpose.

Jakarta provincial government finally decided the minimum wage 2017 is IDR 3,335,750 (http://bisnis.liputan6.com/read/2637688/dki-jakarta-tetapkanumr-2017). From the above result, it can be seen that most of the customers are on the top management level with high income because their income is much higher than the average wage.

Table 1. Respondents Characteristics

\begin{tabular}{|c|c|c|c|}
\hline No & Character & Frequency & Precentage $(\%)$ \\
\hline \multirow[t]{3}{*}{1} & Gender: & & \\
\hline & a. Male & 71 & $59,16 \%$ \\
\hline & b. Female & 49 & $40,84 \%$ \\
\hline \multirow[t]{6}{*}{2} & Age: & & \\
\hline & a. $<20$ years old & 0 & $0 \%$ \\
\hline & b. $21-30$ years old & 19 & $15,83 \%$ \\
\hline & c. $31-40$ years old & 54 & $45 \%$ \\
\hline & d. $41-50$ years old & 42 & $35 \%$ \\
\hline & e. $>50$ years old & 5 & $4,17 \%$ \\
\hline \multirow[t]{6}{*}{3} & Education: & & \\
\hline & a. High School & 0 & $0 \%$ \\
\hline & b. Diploma & 15 & $12,5 \%$ \\
\hline & c. Bachelor of Science Degree (S1) & 71 & $59,16 \%$ \\
\hline & d. Magister of Science Degree (S2) & 28 & $23,34 \%$ \\
\hline & e. Doctor $(\mathrm{S} 3)$ & 6 & $5 \%$ \\
\hline \multirow[t]{7}{*}{4} & Occupation: & & \\
\hline & a. Student & 0 & $0 \%$ \\
\hline & b. College Student & 3 & $2,5 \%$ \\
\hline & c. Government Employee & 29 & $24,16 \%$ \\
\hline & d. Private Employee & 74 & $61,67 \%$ \\
\hline & e. Entrepreneur & 14 & $11,67 \%$ \\
\hline & f. Others & 0 & $0 \%$ \\
\hline \multirow[t]{4}{*}{5} & Visit to Fairmont Jakarta every month: & & \\
\hline & a. $<2$ & 74 & $61,66 \%$ \\
\hline & b. $2-7$ & 38 & $31,67 \%$ \\
\hline & c. $>7$ & 8 & $6,67 \%$ \\
\hline \multirow[t]{5}{*}{6} & Monthly Income: & & \\
\hline & a. IDR 5.000.001 - IDR 15.000 .000 & 5 & $4,16 \%$ \\
\hline & b. IDR $15.000 .0001 \quad-\quad$ IDR & 46 & $38,34 \%$ \\
\hline & 30.000 .000 & 69 & $57,5 \%$ \\
\hline & c. $>$ IDR 30.000 .000 & & \\
\hline
\end{tabular}

TRJ Tourism Research Journal, Volume 1 (1), 2017 


\section{Normality Test}

Normality test showed that the data spreads around the diagonal line and follows the direction of the diagonal line, and then the regression model meets the assumption of normality (Figure 2).

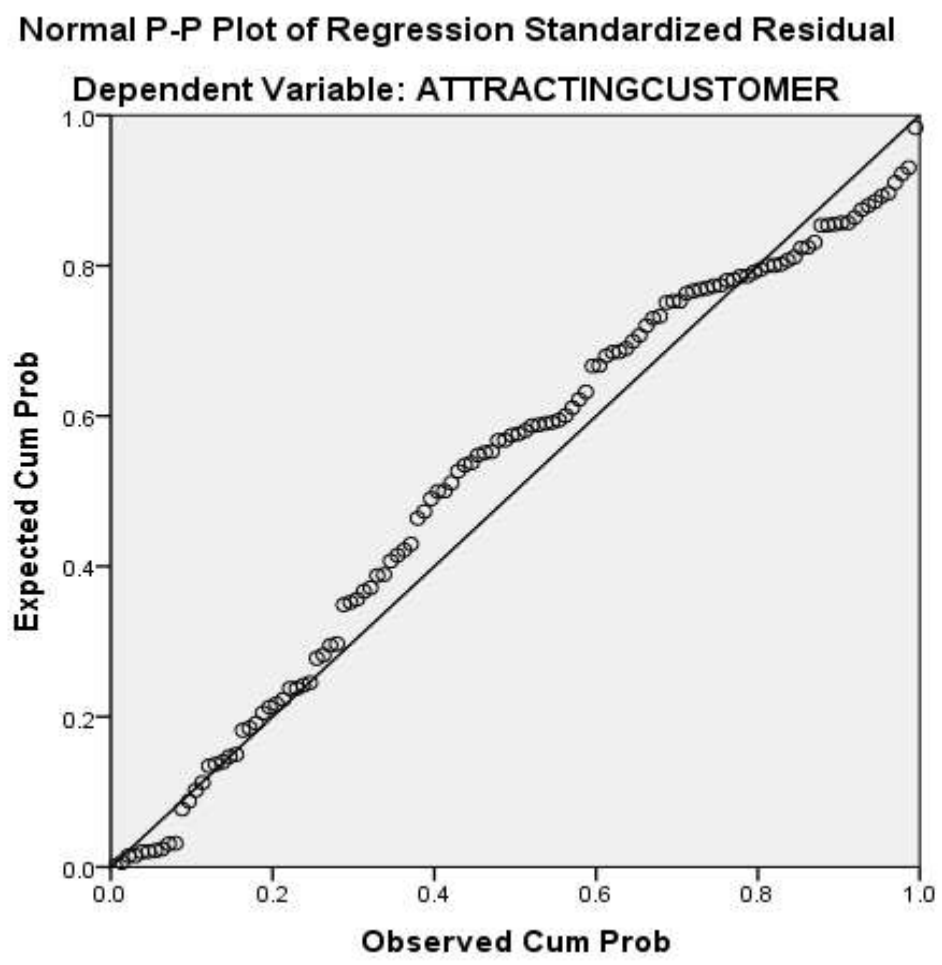

Figure 1. Normality Test

\section{Multicollinearity Test}

Multiple collinear (multicollinearity) is a same strong linear connection between the independent variables in multiple regression model. This mutilple collinear will make unstable assumption_coefficient.

\section{Multiple Regression Test}

The result of multiple regression Test could be described in Table 2 . Independent variable influence dependent variable partially. The explanation are as follow:

Firstly, the effect of advertising on purchasing decisions is -0.548 with a value of $t$ arithmetic -4.149 (value Sig $0.000<0.05$ ). It indicates that advertising has negative and significant affect to attract customer. This means that any increase in location by 1 point will decrease visitor level by .548 points. 
The second, the influence of sales promotion in attracting costumer is 0.772 with $t$ value 4.397 (Sig $0.000<0,05$ ). It indicates that sales promotion has positive and significant influence to Attract customer. It means that any increase in location by 1 point will improve the purchase decision of guests 0.772 points.

The third, the influence of public relation on attracting customer is -0.010 with $t$ value of -137 (Sig 0.891>0,05) indicates that public relation has negative but doesn't have significant influence to attract customer.

The fourth, the effect of personal selling on attracting customer is 0.190 with a value of $t$ count of 3.360 (Sig $0.001<0,05$ ). It indicates that personal selling has positive and significant influence to attract customer. It means that any increase in location of 1 point will increase purchasing decision guests 0.190 points.

The fifth, the effect of direct marketing on attracting customer is 0,009 with value of $\mathrm{t}$ count 0.121 (value of Sig $0.904>0,05$ ). It shows that direct marketing has positive but doen't have significant effect to attract customer.

Table 2. The Result of Multiple Regression Test

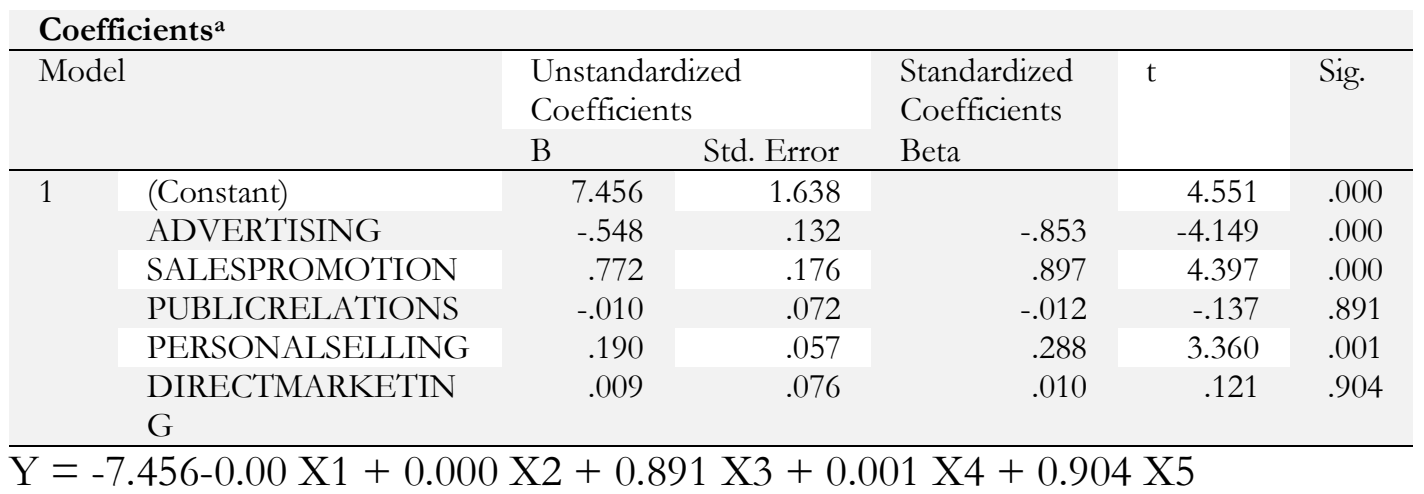

\section{F-test}

If Anova test result has Sig value $0.000<0.05$, it means that Ha received. So that the variable of advertising, sales promotion, public relations, personal selling, and direct marketing affect simultaneously to Attracti customer at Fairmont Hotel Jakarta. In other words, without a good advertising, sales promotion, public relation, personal selling, and direct marketing strategy, the hotel will result in lowail to attract costumer.

\section{Coefficient Determination $\left(\mathbf{R}^{2}\right)$}

The result analysis of coefficient determination $\left(\mathrm{R}^{2}\right)$ could be seen in table 3. From the table can be read that the value of $R$ square $\left(R^{2}\right)$ is 0.229 . It means that advertising, sales promotion, public relations, personal selling, direct 
marketing are influent to attract customer 22.9\%. And around $77.1 \%$ it's influent by another variable.

Table 3. Coefficient Determination $\left(\mathrm{R}^{2}\right)$

\begin{tabular}{lllll}
\multicolumn{3}{l}{ Model Summary } \\
\hline $\begin{array}{l}\text { Mo } \\
\text { del }\end{array}$ & $\mathrm{R}$ & $\begin{array}{l}\mathrm{R} \\
\text { Square }\end{array}$ & $\begin{array}{l}\text { Adjusted R } \\
\text { Square }\end{array}$ & $\begin{array}{l}\text { Std. Error } \\
\text { of } \\
\text { Estimate }\end{array}$ \\
\hline 1 & $.479^{\mathrm{a}}$ & .229 & .195 & 1.95389 \\
\hline
\end{tabular}

\section{E. Conclusion}

Based on above explanation, most of the customers of Faimont Hotel Jakarta are considered as Generation X. Their age is among 31-50 years old. According to Journal of Behavioral Studies in Business, the characteristics, lifestyles, and attitudes of Generation X include balancing family, life, and work (Williams and Page: 2017). Hence, this means that the people who come to Fairmont Hotel Jakarta are those with stable career and income compare to other generations, such as generation $\mathrm{Y}$.

Getting attention of $\mathrm{X}$ generation is not easy. This type of respondent can be considered as highest-value customers. Not only have they had the capability for higher consumption, but they also have loyalty and trust.

The study found that marketing communication that consisted of advertising, sales promotion, public relation, personal selling and direct marketing impacted to attract customers $22,9 \%$. Based on data processing sales promotion, personal selling had positive and significant impact to attract the customers. Direct marketing had positive but didn't have significant impact to attract the customers. public relation and advertising had negative impact to attract the customers. Advertising and public relations didn't have any impact to attract the customers.

Based on the research, there are some recommendations. In terms of advertising, Fairmont Hotel Jakarta is suggested to conduct advertising to specific market target of $\mathrm{X}$ generation with more stable and high income. According to respondent profile, it was concluded that customers of Fairmont Hotel Jakarta are mostly X generation. X generation wants to hear the features of the product as well as an explanation of why these features are necessary. Moreover this group is most price conscious and they have low price sensitivity. They want product and messages designed uniquely for their tasks and lifestyles. Information and technology are important in products and services. They see technology as changing their world and techno literacy is highly valued. (Williams

TRJ Tourism Research Journal, Volume 1 (1), 2017 
and Page:2017). Hence, focusing more on advertisement involving technology might be a good strategy to do in attracting customers. $\mathrm{X}$ generation tend to be more demanding in terms of choosing certain product, the advertisement has to be attractive in getting customers Fairmont Hotel Jakarta attention.

In terms of sales promotion, these approaches are effective and significant in attracting customers of Fairmont Hotel Jakarta. Therefore, Fairmont Hotel Jakarta should maintain the sales promotion strategy and enhance with innovation and ideas following to the latest trends and updates.

In terms of personal selling, it is considered as effective strategy in attracting customers. Fairmont Hotel Jakarta should maintain the strategy and enhance its quality. It can be conducted by using strategy in approaching the target market. The sales person needs to approach customers as consultant and treat them as family. X generation demands trust, treat them like family. Give them plenty of access to information and educate them into buying. Keep them in the loop by asking for their feedback and sharing information with them regularly. It is effective to approach them more as consultant rather than seller. They like to be kept abreast for the bigger picture (Williams and Page: 2017).

In terms of direct marketing, direct marketing is not a recommended marketing strategy to conduct in attracting customers. The budget for direct marketing can be allocated to another marketing communication.

In terms of public relation, it's suggested that Fairmont Hotel Jakarta isn't focusing on this strategy in attracting customers.

Finally, Fairmont Hotel Jakarta should enhance their efforts and capabilities in applying an effective marketing communication strategy, in order to increase the total number of customers. Increase visit means enhance income of Fairmont Hotel Jakarta.

\section{F. Acknowlegement}

1. Djoko Sudibyo, SE, MM, Phd as Managing Director Master Program of Sekolah Tinggi Pariwisata Trisakti.

2. Dr. Adinoto Nursiana, SE, MM as my Thesis Advisor 1.

3. Dr. Chondro Suryono, SE, MM as my Thesis Advisor 2.

\section{REFERENCES}

Adcock, A.H., and Caroline R.( 2001). Marketing Principles \& Practice. London: Ashford Colour Press Ltd, American Hotel \& Lodging Association, bttps: / www.abla.com/.

Arikunto, S. (1996). Prosedur Penelitian Suatu Pendekatan Praktis, Edisi Revisi Enam, Cetakan Ketigabelas, Jakarta :Rineka Cipta.

Belch, G.E., and Michael, A. B.(2001). Advertising and Promotion: an Integrated

TRJ Tourism Research Journal, Volume 1 (1), 2017 
The Impact of Marketing Communication in Attracting Customer (Case Study at Fairmont Hotel Jakarta)

Marketing Communication Perspective Fifth Edition. New York: McGrawHillIrwin.

Biro Administrasi Akademik.(2005). Pedoman Akademik, Yogyakarta : UAD Press.

Burns, A.C., and Ronald F. B.(2006). Marketing Research. New Jersey: Pearson Education. Inc.

Cangara, H.(2004). Pengantar Ilmu Komunikasi. Jakarta: PT. Raja Grafindo Persada.

Cooper, D.R., and Pamella, S.S. (2002). Business Research Methods. New York:McGraw-Hill.

Creswell, J.W., and Vicki, L.P.C. (2007). Mixed Method Research. London: Sage Publication Ltd.

Daymon, C. and Holloway, I. (2002). Qualitative Research Methods in Public Relations and Marketing Communications. London: Routledge.

Deacon, D., et al.(1999). Researching Communications: A Practical Guide to Method on Media and Cultural Analysis. London: Arnold.

Deco Agency.(2017). bttp:/ / www.cleverism.com/ understanding-marketing-mixconcept-4ps.

Durianto, Darmadi, Sugiarto, Tony S.(2001). Strategi Menaklukean Pasar Melalui Riset Ekuitas dan Perilaku Merek. Jakarta: Gramedia Pustaka Utama.

Durianto, ddk, $2001: 127$.

Fourhooks.com, http://fourhooks.com/marketing/the-generation-guidemillennials-gen-x-y-z-and-baby-boomers

Effendy, O.U. (2004). Ilmu Teori Komunikasi Teori dan Praktek. Jakarta: PT. Remaja Rosdakarya.

Hadi, S.(1996). Teknik Riset dan Peramalan Penjualan, Yogyakarta : Andi Offset.

Hermantoro, H. (2015). Kepariwisataan Destinasi Pariwisata Produk Pariwisata. Jakarta: CV Aditri.

Khumaedy, M. A.(2017). Humas Sekretariat Kabinet Republik Indonesia, bttp:/ / setkab.go.id/ tabun-2017-kita-genjot-sektor-pariwisatal

Kotler, P. and Keller. (2006). Marketing Management. Twelve Edition. New Jersey: Practice Hall.

Kotler, P. (1997). Manajemen Pemasaran, Edisi Bahasa Indonesia, Jilid 1, (Terjemahan : Teguh, Hendra dan Rusli, Ronny) : Prenhallindo, Jakarta.

Kotler, P. (2000). Marketing Management. New Jersey: Prentice-Hall.

Mediapost, https://www.mediapost.com/publications/article/255539/gen-xersdo-not-give-away-brand-loyalty.html

Mela, Gupta and Donald R. L. (1997). The Long-Term Impact of Promotion and Advertising on Consumer Brand Choice. Journal of Marketing Research.

Menofriadi, E.(2007). Pengarub Bauran Promosi Terhadap Penjualan Produk Kosmetik Puteri. Jurnal LSPR.

Papalia, D.E., Olds, S.W., and Feldman, R.D. (2007). Human Development,10th edition. New York: McGraw-Hill.

TRJ Tourism Research Journal, Volume 1 (1), 2017 
The Impact of Marketing Communication in Attracting Customer (Case Study at Fairmont Hotel Jakarta)

Peter, J.P., dan Olson, J.C.(2000). Consumer Behavior: Perilaku Konsumen dan Strategi Pemasaran, Edisi Keempat, Jilid 2, (Terjemahan : Sihombing, Damos), Jakarta : Erlangga.

Picton, D. and Amanda, B.(2001). Integrated Marketing Communication. England: Perason Education.

Rangkuti, F.(2002). The Power of Brands: Teknik Mengelola Brand Equity dan Strategi Pengembangan Merek. Jakarta : Gramedia Pustaka Utama.

Ruben, B.D.(1992). Communication and Human Behavior. New Jersey: A Simon \& Schuster Company.

Sambodo, A. and Bagyono.(2006). Dasar-dasar Kantor Depan Hotel. Yogyakarta: Penerbit Andi.

Swasta, B. and Handoko, T. H. (1987). Manajemen pemasaran : Analisis Perilaku Konsumen, Yogyakarta : Liberty.

Swasta, B. and Irawan.(2008). Manajemen pemasaran Modern, Edisi Kedua, Cetakan Kesepuluh, Yogyakarta : Liberty.

Tjiptono, F.(1997). Strategi Pemasaran, Edisi Kedua, Cetakan Pertama, Yogyakarta : Andi Offset.

Tribe, J.(1996). Corporate Strategy ForTourism.

William and Page.(2017). Journal of Behavioral Studies in Business.

Wirtz, Jochen, P.C., and Lovelock, C.(2013). Essentials of Services Marketing 2nd Edition. Singapore: Pearson Education South Asia Pte Ltd.

Veal, A.J.(1997). Research Methods for Leisure and Tourism A Practical Guide Second Edition.Trowbridge, Wiltshire: Financial Times Management.

Verhoef, P.C. (2003). Understanding the Effect of Customer Relationship Management Efforts on Costumer Retention and Customer Share Development. Journal of Marketing. 